RISUS - Journal on Innovation and Sustainability ISSN 2179-3565
RISUS - Journal on Innovation and Sustainability volume 11, número 3 - 2020

ISSN: $2179-3565$

Editor Científico: Arnoldo José de Hoyos Guevara Editor Assistente: Rosa Rizzi

Avaliação: Melhores práticas editoriais da ANPAD

\title{
CONVERSION OF AN INFORMATION AND COMMUNICATION TECHNOLOGY CLUSTER TO A POLE OF CREATIVE ECONOMY: AN ANALYSIS FROM THE PERSPECTIVE OF SÉRGIO ALVES' MULTIDIMENSIONAL-REFLEXIVE MODEL OF ORGANIZATION
}

\section{Conversão de um Cluster de Tecnologia da Informação e Comunicação para um Polo de Economia Criativa: uma análise da perspectiva do Modelo de Organização Multidimensional-Reflexivo de Sérgio Alves}

\author{
Anderson Diego Farias da Silva ${ }^{1}$, Osíris Luís da Cunha Fernandes ${ }^{2}$, Fernando Gomes de Paiva Júnior ${ }^{3}$, \\ Janann Joslin Medeiros ${ }^{4}$, Nelson da Cruz Monteiro Fernandes ${ }^{5}$ \\ ${ }^{1}$ Centro Universitário Facol, ${ }^{2,4,5}$ Universidade Federal de Pernambuco, ${ }^{3}$ Universidade de Brasília, Brasil. \\ E-mails: andersondiego6@gmail.com, osiriscunha@gmail.com, fernandopaivajr@gmail.com, \\ janmedeiros@gmail.com, cruzfernandes55@gmail.com,
}

\begin{abstract}
This study examines how structure and agent are manifested during the process of conversion of the Porto Digital, an urban Local Productive Arrangement (LPA) for Information and Communication Technology (ICT) domiciled in the Metropolitan Region of Recife in the Brazilian state of Pernambuco, into a Creative Economy pole entitled Portomídia. An embedded case study was carried out using the multidimensional-reflexive model of organization (OMR) proposed by Sérgio Alves. The compilation of the corpus for analysis included the transcriptions of semi-structured interviews and field observation notes, as well as documents associated with the conversion effort. Results indicate that the organizational-administrative characteristics of Portomídia approximate the liberating-transformational ideal type described by Alves' multidimensional-reflexive model, a format characterized by the presence of agents with charismatic leadership traits and the primacy of agent over structure.

Keywords: Local Productive Arrangement, Porto Digital, Portomídia, Organizational Analysis, Multidimensional-Reflective Model.
\end{abstract}

ACEITO EM: 10/02/2020

PUBLICADO: 30/09/2020 


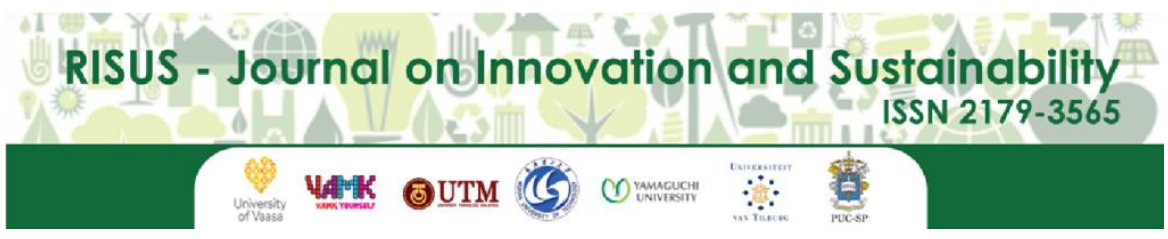

RISUS - Journal on Innovation and Sustainability volume 11, número 3 - 2020

ISSN: $2179-3565$

Editor Científico: Arnoldo José de Hoyos Guevara Editor Assistente: Rosa Rizzi Avaliação: Melhores práticas editoriais da ANPAD

\title{
CONVERSÃO DE UM CLUSTER DE TECNOLOGIA DA INFORMAÇÃO E COMUNICAÇÃO PARA UM POLO DE ECONOMIA CRIATIVA: UMA ANÁLISE DA PERSPECTIVA DO MODELO DE ORGANIZAÇÃO MULTIDIMENSIONAL- REFLEXIVO DE SÉRGIO ALVES
}

Conversion of an Information and Communication Technology Cluster to a Pole of Creative Economy: an analysis from the perspective of Sérgio Alves' Multidimensional-Reflexive Model of Organization

\author{
Anderson Diego Farias da Silva ${ }^{1}$, Osíris Luís da Cunha Fernandes ${ }^{2}$, Fernando Gomes de Paiva Júnior ${ }^{3}$, \\ Janann Joslin Medeiros ${ }^{4}$, Nelson da Cruz Monteiro Fernandes ${ }^{5}$ \\ ${ }^{1}$ Centro Universitário Facol, ${ }^{245}$ Universidade Federal de Pernambuco, ${ }^{3}$ Universidade de Brasília, Brasil. \\ E-mails: andersondiego6@gmail.com,osiriscunha@gmail.com, fernandopaivajr@gmail.com, \\ janmedeiros@gmail.com, cruzfernandes55@gmail.com,
}

\section{RESUMO}

Este estudo examina como a estrutura e o agente se manifestam durante o processo de conversão do Porto Digital, um Arranjo Produtivo Local Urbano (APL) para Tecnologia da Informação e Comunicação (TIC) domiciliado na Região Metropolitana de Recife, no estado Pernambuco, em um polo de Economia Criativa intitulado Portomídia. Foi realizado um estudo de caso incorporado, utilizando o Modelo de Organização Multidimensional-Reflexivo (OMR) proposto por Sérgio Alves. A compilação do corpus para análise incluiu transcrições de entrevistas semiestruturadas e notas de observação de campo, além de documentos associados ao esforço de conversão. Os resultados indicam que as características organizacionais-administrativas do Portomídia se aproximam do tipo ideal libertador-transformacional descrito pelo Modelo de Organização MultidimensionalReflexivo de Alves, formato caracterizado pela presença de agentes com traços carismáticos de liderança e pela primazia do agente sobre a estrutura.

Palavras-chave: Arranjo Produtivo Local, Porto Digital, Portomídia, Análise Organizacional, Modelo de Organização Multidimensional-Reflexivo. 


\section{INTRODUCTION}

In view of the phenomena of globalization, expressed in the process of productive restructuring, in which we observe the increase in competitiveness, the new demands of connected consumers, the increased differentiation between products and the intensification of networks, has demanded the emergence of a great variety of ways to set up and promote collaborative action among organizations for shared goals (Castells, 2016; Julien, 2010). One of these collaborative actions between organizations is materialized through Local Productive Arrangements (LPA), which can be defined as dynamic environments where economic, social and political actors interact to promote a set of specific economic actions (Etzkowitz and Leydsorff, 1997; Kirschbaum et al., 2009; Mazzucao and Penna, 2016; Lee et al., 2020). This conception is shared by Cassiolato \& Lastres (2003), Lastres and Cassiolato (2010) and Howels (2019), who point to these arrangements as spaces constituted by the participation and interaction between companies, clients, business representatives and public institutions, which are involved to establish synergies and share mechanisms for the development of their expertise.

Ouyang et al. (2017) confirm this scenario when they highlight the practical dimension of established publicprivate policies in order to articulate collaborative actions between industry, academia and governments as productive systems known as Centers for Collaborative Innovation (CICs). These centers, operated under the coordination of IBM, are examples of a three-way triple helix intelligent service system designed to reduce skill gaps and accelerate the growth of skilled jobs that are central to regional economic development.

The dynamics of these productive agglomerations are fueled by systemic changes brought about by the globalization of markets in the midst of the development of new Information and Communication Technologies (ICTs). In these scenarios, the contours of the spaces that constitute object of intervention associated with the interests of the actors involved with new quality systems, concern with social responsibility and operation in business network environments are configured and require a set of institutional equipment to ensure effective operational support, such as those in science and technology parks (Knorringa and Nadvi, 2016).

Over the last decade, the European Union has invested in a technology-intensive economy. In order to problematize the reality of actors engaged in innovation clusters in Brussels (Belgium), Teirlinck (2017) conceives that these services include the area of computing and related activities, research and experimental development and business practices articulated in business networks using interactive digital tools. They rely on the highly specialized knowledge of intensive support to the business processes of other organizations.

The science and technology parks are types of clusters with technology-intensive services recognized as habitats of innovation and entrepreneurship, through which infrastructure and specialized services are enabled to provide local technological and economic development. In addition to boosting business activity, generating employment, income and even a possible configuration of smart cities, as highlighted by Dattagupta (2014), the leaders of these types of park seek to make efforts to attract companies, incubators and startups accelerators, in which they operate innovative sectors in the mobilization of efforts together with actors of their business network as they work to expand their enterprises, consolidate their shared action practices and promote technological development (Minguillo, Tijssen and Thelwall, 2015).

The Local Productive Arrangement (LPA) of Information and Communication Technology (ICT) and Creative Economy, denominated Porto Digital (PD) is an environment of entrepreneurship, innovation and business intensive in ICT, located in Recife Antigo, Pernambuco. Through a regulatory process, the Porto Digital promoted in 2011 it is expansion to the Creative Economy area, by expanding it is scope of action and opportunizing the emergence of a new technological system directed to embark the companies of this sector. This collective undertaking was designated Portomídia - Center of Entrepreneurship and Technology of the Creative Economy. Therefore, this conglomerate seeks to combine specialized knowledge and resources in order to operationalize the development of their respective artifacts (Porto Digital, 2010; 2020; Cictec, 2013).

We intend to understand the process of [re]signification of the Pernambuco LPA ICT that expanded its institutional scope in order to incorporate another institutional arrangement that includes sectors of Creative 
Economy, the Portomídia, discussed from the theoretical perspective of the Multidimensional-Reflective Organization (OMR), developed by Alves $(2003 ; 2004)$. Therefore, the structural and agency characteristics

related to the LPA Porto Digital are revealed in order to understand how the process of extending this arrangement encompassed the technological system Portomídia.

The ideal type perspective is considered to be the basis of Max Weber's epistemological doctrine, since it is based on the need for the researcher to approach the phenomenon under analysis (Alves, 2003; 2004). The analytical development of the ideal types in Weber's approach $(1999,1985)$ follows a framework that starts from the articulation of a set of phenomena in isolation, since they are ordered to constitute a homogeneous view of thought (Moraes et al., 2003).

The studies of Alves $(2003,2004)$ present us with the possibility of understanding how pure structures of domination must be organized through the integration of their elements of analysis. Therefore, the ideal mechanism for combining ideal types is to articulate their constituent elements as variables of an analytical model. Bertero (1981) states that the use of typologies corroborates in the improvement of organizational theory. This author points out that the connection of the Weberian ideal types contributes to the formulation of a typology representative of the modes of legitimate domination.

The application of the theoretical-analytical model of Multidimensional-Reflective Organization (OMR) proposed by Alves $(2003 ; 2004)$, based on the Weberian epistemological perspective, reveals the intention to investigate structural formations and administrative configurations. OMR is conceived as "a construct [...] to represent a more complex and comprehensive object, with the purpose of being understood a set of characteristics that more interest in certain conditions" (Alves, 2003, p. 13).

In this sense, the academic contribution of this study consisting of application of the OMR model to the analysis of an LPA, from a case study whose results must generate a comprehensive view regarding these organizational formats governed by interference of public-private organizations. In addition, we will observe how the interorganizational relationships are developed, the role of agents and the organizational dynamics with respect to their administrative activities.

From the analytical categories 'manifestation of structure' and 'agency', answers we sought for the following central question: how does the process of conversion of the Porto Digital in the Portomídia in it is organizational-administrative format occur?

In order to answer this research question, the article was structured as follows: 1. Introduction, presenting the problem of the study; 2. theoretical reference, at which point we present the theoretical lens that will allow us to investigate the aforementioned empirical case of LPA Porto Digital, constituted through the following subsections: 2.1. The Multidimensional-Reflexive Model of Organization (OMR); 3. Methodological-Analytical Procedures, in which we present the tracks used to carry out the investigation; 4. The Technological System Portomídia, chapter intended to present the context of the empirical case; 5. Results and discussion, chapter intended to present the empirical evidence analyzed from the theoretical lens constituted, divided by the following subsections: 5.1. Institutional Environment of LPA Porto Digital, 5.2. Structural Characteristics and Coordination Devices, 5.3. Characteristics and mode of action of the Agent, 5.4. Activity Flows, 5.5. LiberatingTransformational Format; 6. Final Considerations, space intended for our final allegations, response of the research question and suggestions for future research developments.

\section{THEORETICAL FRAMEWORK}

There are fundamental aspects in this debate that constitute the Weberian epistemological premise about the ideal types of domination. The theoretical model of Multidimensional-Reflective Organization (OMR) developed by Alves $(2003 ; 2004)$ presents a comprehensive approach with respect to the logic of power and domination present in the articulations of actors in the rearrangement of a technological cluster that aggregates dimensions of the relative creative economy to business, art, entertainment and science and technology. 


\subsection{The Multidimensional-Reflective Model of Organization (OMR)}

The theoretical Multidimensional-Reflective Model of Organization (OMR) developed by Alves (2003; 2004) is based on the interaction between the ideal types of Weberian domination, as described in the previous section (Weber, 1999). The proposal of the approach resides in discussing the interaction between the individual and the organization-system "as dimensions intrinsically linked and conditionally reciprocally" (Costa, 2011, p. 42).

This model is the result of the articulation of primordial elements to the understanding of Weberian ideal types, namely: charisma, patriarchy and bureaucracy, and which have been combined as analytical variables (Table 1) that can aid in the analysis of new formations such as Local Productive Arrangements (LPA).

In the OMR format, the first dimension refers to the concept of "charism", which is comprised of two spheres: genuine (idealized) charisma and objective charisma (with traditional and rational bases). The charism, therefore, is not linked to the values of the individual, for, according to Maurizio Bach, in his work entitled "Charism and rationalism in Max Weber's sociology" the type of charismatic domination removes the past from its scope and reveals itself a revolutionary typology (Bach, 2011).

The concept of "patriarchy" (second dimension of the OMR) is described as the fruit of the personification of the patriarch through tradition and acquired family values (Alves, 2004). In the case of organizations, this patriarchal component would be related to individuals associated with degrees of kinship, trust, dedication, loyalty and cooperation process. As Aguiar (2000) argues, the question of patriarchy is tied to the bureaucratic state in the context of patriarchal patrimonialism. In what concerns the variability that characterizes the type of patriarch, Alves (2003) points out that this is constituted through the spheres (degrees) of qualification. That is, when it is called the maxim, the author calls it a patriarchal reformer; when it is intermediate, the constituted the profile of renovating patriarchal and; finally, when it is considered minimal, it is called conservative patriarchal.

In the third dimension of the OMR, the "bureaucracy", Alves (2003) considers that no organization has a limit that determines it as being more or less bureaucratized. Thus, according to the author, for the bureaucrat, the leader of business organizations is that more or less "rigid" individual, as his or her company is close to the ideal type of bureaucracy. Guerreiro Ramos (2006, p. 273) adds that "bureaucratic administration [is that] in which the servile relationship between the sovereign and the official, who in this case is personally free, disappears altogether".

Alves (2003) presents formats of organizations and their varied degrees of bureaucratic structure in order to illustrate business models linked to the ideal type of bureaucracy, such as full bureaucracy (high concentration of authority, for example); full blown bureaucracy (characteristics similar to the type presented earlier but, to a lesser extent); workflow bureaucracy (low concentration of authority, for example); bureaucracy of personnel (low structuring of activities); nascent bureaucracy of workflow (weak control and very low concentration of activity, for example); and pre-bureaucracies of workflow (strong control of tasks). In addition, the author highlights the relationship between his model (OMR) and instrumental rationality, because of its association with the company's technical-economic performance. In addition, the author assumes that the model developed does not necessarily include all business organizations and models.

We conclude partially that the OMR model has a point of convergence with the contingency perspective. It is also based on the fact that organizations have dimensions of temporality, that is, such a model is linked to the understanding of aspects related to the past (habits and customs in company history), the present (immediate experience and continuous flow) and the future (emphasizing the future), which are related to each other. 
Table 1 - Description of the OMR model

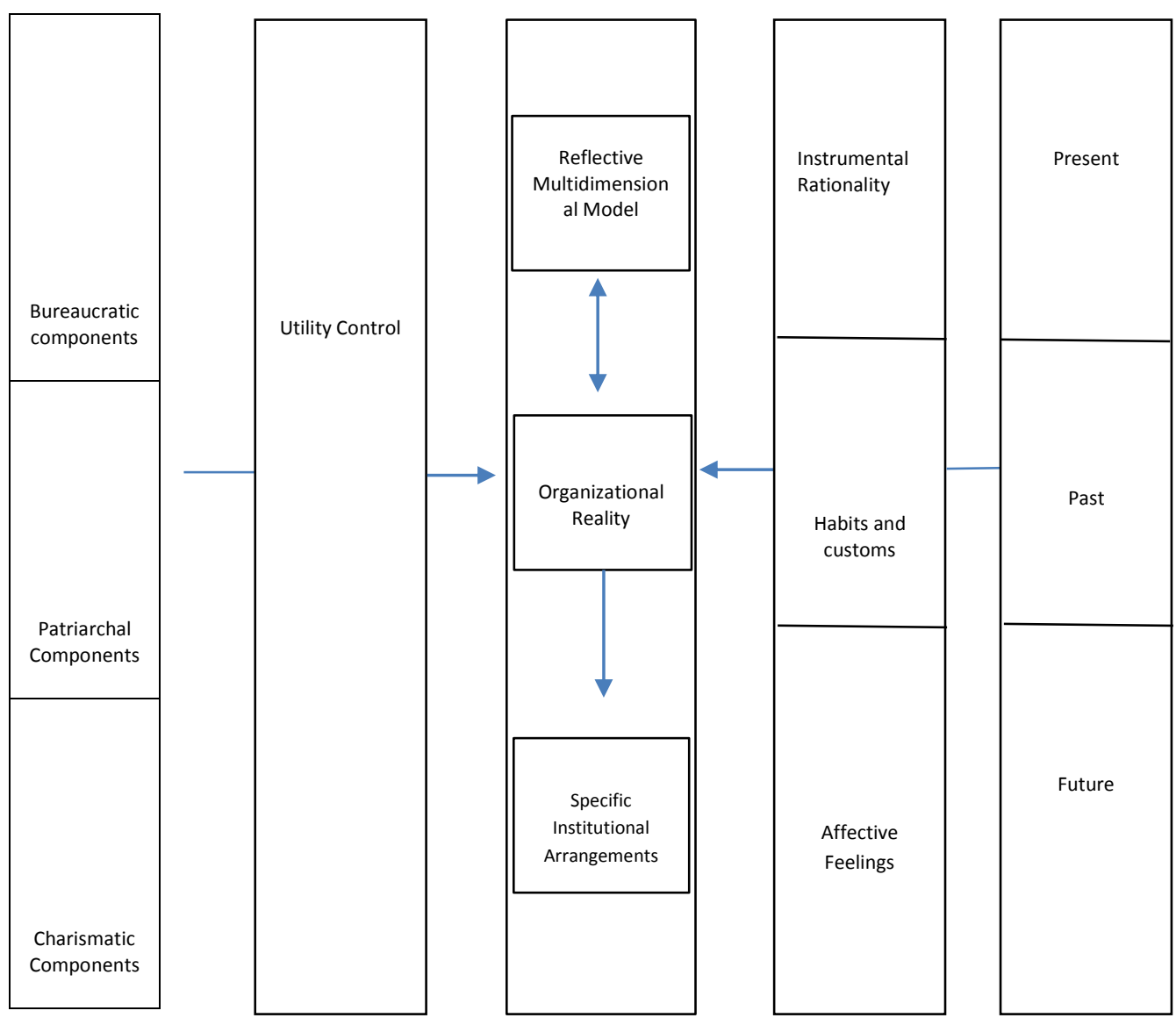

Source: Adapted from Costa (2011) and Alves (2003)

The Multidimensional-Reflective Model of Organization by Alves (2003) has contributed to the increase of research inspired by the pure structures of domination conceived by Weber $(1999,1985,1974)$, revealed in the study of Lins \& Correia (2008) "The Case Nissan: overcoming the leadership antinomy vs. bureaucracy?". In turn, this is also illustrated in the studies by Almeida \& Paula (2013) entitled "Application of the multidimensional-reflexive model for the analysis of a municipal public entity: Sports and Recreation Authority of Recife (PE)" and developed by Xavier Filho et al. (2013) with respect to "Withdrawal of Cooperation in Horizontal Interorganizational Networks: Reflections from the Typology of Weberian Social Action".

\subsubsection{The conception of structural types and subtypes}

The conception of structural types and subtypes is based on the aim of making this study feasible as a support for the organizational-administrative format of the Pernambuco LPA ICT, denominated Porto Digital, designed in it is expansion process for the status of a creative economy arrangement, through the creation of the Portomídia and treated as an analytical basis of the institutional reality in it is totality. Therefore, it is necessary to understand the hybrid structural types that are conceived from the OMR and serve as reference for the analytical construction of this study, according to the description of types and subtypes dispose on the Table 02. 
CONVERSION OF AN INFORMATION AND COMMUNICATION TECHNOLOGY CLUSTER TO A POLE OF CREATIVE ECONOMY: AN ANALYSIS FROM THE PERSPECTIVE OF SÉRGIO ALVES' MULTIDIMENSIONAL-REFLEXIVE MODEL OF ORGANIZATION ANDERSON DIEGO FARIAS DA SILVA, OSÍRIS LUÍS DA CUNHA FERNANDES, FERNANDO GOMES DE PAIVA JÚNIOR, JANANN JOSLIN MEDEIROS, NELSON DA CRUZ MONTEIRO FERNANDES

Table 2 - Types of organizational-administrative formats and their structural and agent characteristics

\begin{tabular}{|l|l|l|}
\hline \multicolumn{1}{|c|}{$\begin{array}{c}\text { Ordaining - Conservative } \\
\text { Format }\end{array}$} & Balancing -Adaptive Format & \multicolumn{1}{c|}{$\begin{array}{c}\text { Liberating - } \\
\text { Transformational Format }\end{array}$} \\
\hline Structural Characteristics & Flexible bureaucracy & Incipient bureaucracy \\
\hline Rigid bureaucracy & Renovating patriarchy & Reformist patriarchy \\
\hline Traditionalist patriarchy & $\begin{array}{l}\text { Leadership with accentuated } \\
\text { charismatic characteristics }\end{array}$ \\
\hline Agent Characteristics & $\begin{array}{l}\text { Leadership without charisma } \\
\text { (objective charisma) }\end{array}$ &
\end{tabular}

Source: Adapted from Costa (2011) and Alves (2004).

The Ordaining-Conservative format is a structural type presents as subtypes: the conservative patriarch, the traditionalist and the rigid bureaucratic. Thus, the predominant actor in this type of structure is the Conservative Multidimensional-Reflective Organizational Agent (AMR), on which the organization-system prevails. In practice, this type of organization model is recognized as one that resists change, has a restriction on creative autonomy, in which the limitation to innovate and the profusion of customary regulations and practices are observed. For this reason, according to Alves (2004), this type of organization has difficulties in operating satisfactorily in complex, dynamic and competitive scenarios.

The Balancing-Adaptive is a format describes an organization which maintains a dynamic equilibrium between change and stability, flexibility and rigidity, autonomy and control, innovation and routine. It results from a combination of components from the flexible bureaucratic and renovating patriarchy structures of organization. Leadership is characterized by an attenuated charisma in which the agent is an adapter. In this organizational-administrative format, neither structure nor agent predominates (Alves, 2004).

Finally, the liberating-transformational format describes an organization in which change, flexibility, originality and innovation are emphasized. In this format charismatic leadership is combined with structures of reforming patriarchy and structures in which bureaucratic elements, if present, are only incipient. The typical agent, in this format, is a transformer and agent action tend to predominate over structure (Alves, 2004).

\section{METHODOLOGICAL-ANALYTICAL PROCEDURES}

The methodological approach used to carry out this study was the qualitative one, so as to enable us, from the meanings conferred by social actors raised (Creswell, 2010; Denzin; Lincoln, 2006), to understand how the manifestation of structure and agency occurs in the process of conversion of LPA of TIC Porto Digital, in Portomídia, a pole of Creative Economy domiciled in the Metropolitan Region of Recife (PE), through of Multidimensional Reflective Organization (OMR) model (Alves, 2004; 2003). Therefore, it was plausible to interpret the phenomenon through an embedded case study (Creswell, 2010), which proved appropriate considering the contextual conditions of the investigative locus to be pertinent to the understanding of the problematic raised.

The study is characterized as a single embedded case study. According to Yin (2005), this case study variation occurs when within a single case attention is paid to several of its subunits. Therefore, the Porto Digital was selected as a case study, encompassing the technological system Portomídia - linked to the development of the Creative Economy sectors. As subunits, some of the actors that work in the development of the Creative Economy in the ICT of the Porto Digital are also embedded in the institutional arrangement Portomídia.

In the case of the construction of the analytical corpus, we opted the method of observation because it is considered a significant factor to reach the understanding about the case (Lincoln \& Guba, 1985). In the case study, the establishment of a relationship between certain situations occurs through the application of methods of direct or indirect observational data collection. Another methodological procedure used for the construction of the Corpus was the semi-structured interview, which, according to Table 3, allowed to obtain a historical view of events that could not be witnessed (Stake, 2005; 1995). 
CONVERSION OF AN INFORMATION AND COMMUNICATION TECHNOLOGY CLUSTER TO A POLE OF CREATIVE ECONOMY: AN ANALYSIS FROM THE PERSPECTIVE OF SÉRGIO ALVES' MULTIDIMENSIONAL-REFLEXIVE MODEL OF ORGANIZATION ANDERSON DIEGO FARIAS DA SILVA, OSÍRIS LUÍS DA CUNHA FERNANDES, FERNANDO GOMES DE PAIVA JÚNIOR, JANANN JOSLIN MEDEIROS, NELSON DA CRUZ MONTEIRO FERNANDES

Table 3 - List of respondentes

\begin{tabular}{|c|l|c|}
\hline Cod. & \multicolumn{1}{|c|}{ Institution / Company } & Position \\
\hline E1 & Computer Center - CIN / UFPE & Professor \\
\hline E2 & Hub Criativo & Partner-Founder \\
\hline E3 & Porto Marinho & Founder \\
\hline E4 & Delta Zero Institute & Consulting Board \\
\hline E5 & Gapuia - Culture, Tourism and Communication. & President \\
\hline E6 & Nucleus of Management of the Porto Digital - NGPD & Former Secretary \\
\hline E7 & SECTEC/PE & \\
\hline
\end{tabular}

Source: The authors (2015)

The selection of the Porto Digital cluster is an illustrative case for this discussion, since it constitutes a cluster of ICT companies that demarcate an atmosphere of innovations and, over the years, has managed to materialize as a business-intensive space for technology. The economic fruits of this cluster are a consequence of the action of the local leaders who do not cease to articulate their demands with parastatal institutions, universities and government agencies. In this way, the understanding of contextual conditions is pertinent to understand the phenomenon studied regarding the manifestation of structure and agent in the process of conversion of the Porto Digital, in Portomídia. For this reason, the interviewees were chosen by the degree of relationship and knowledge of the LPA Porto Digital, specifically, with the process of territorial expansion and scope of action of this arrangement in a pole of creative economy.

In addition to conducting semi-structured interviews with the main social actors involved with LPA Porto Digital and the process of its expansion (table 3), we access official documents, reports and legislation, audiovisual material and field notes, in order to find data that allow a more lucid assessment of the case (Stake, 1995; Creswell, 2010).

We chose analytical categories formulated from Alves's Multidimensional-Reflective Organization model (2003; 2004) and their respective operational definitions, as shown in Table 4.

Table 4 - Constitutive and operational definitions from the OMR model

\begin{tabular}{|l|l|l|}
\hline \multicolumn{1}{|c|}{ OMR Analysis Categories } & \multicolumn{1}{|c|}{ Constitutive Definitions } & \multicolumn{1}{c|}{ Operational Definitions } \\
\hline Institutional Environment & $\begin{array}{l}\text { Institutional environment and } \\
\text { interorganizational relations }\end{array}$ & $\begin{array}{l}\text { Legal, political and economic conditions. } \\
\text { Organizations with which maintains a } \\
\text { relationship (Hall, 2004). }\end{array}$ \\
\hline $\begin{array}{l}\text { Structural characteristics and } \\
\text { coordination devices }\end{array}$ & $\begin{array}{l}\text { It results from the combination of } \\
\text { different aspects: nature of the } \\
\text { organization, size, integrating } \\
\text { mechanisms, processes and articulation. }\end{array}$ & $\begin{array}{l}\text { Delegation of authority, communication, } \\
\text { hierarchization, management style: } \\
\text { regulation and control mechanisms, } \\
\text { integration between units. }\end{array}$ \\
\hline Main agent characteristics & $\begin{array}{l}\text { Combination of the elements that } \\
\text { characterize the character of the agent, } \\
\text { approach to time, performance of agents, } \\
\text { availability for changes, and staff. }\end{array}$ & $\begin{array}{l}\text { Orientation that determines the agent's } \\
\text { actions (related to purposes, tradition or } \\
\text { affective feelings), dimension of time } \\
\text { that stands out in the agent's actions } \\
\text { (present, past and future), personal } \\
\text { relationship in the workplace. }\end{array}$ \\
\hline Flow of activities & $\begin{array}{l}\text { Technological advances, systematization } \\
\text { of processes and routines. }\end{array}$ & $\begin{array}{l}\text { With regard to the flow of activities, the } \\
\text { organizational dynamics in relation to } \\
\text { the routines. }\end{array}$ \\
\hline
\end{tabular}

Source: Costa (2011). Adapted by Alves (2003).

During the data interpretation process, triangulation procedures were performed for the data sources, processed and analyzed based on the use of certain sources of information and the triangulation of the researchers, in which more than one researcher could analyze similar contents that reinforce the validation of 
data, seeking to exclude possible misinterpretations (Denzin \& Lincoln, 2006; Gaskel \& Bauer, 2002; Stake, 1999). The triangulation of researchers was carried out with researchers linked to the Research Group in Creative Economy (Lócus) of the Federal University of Pernambuco (UFPE).

\section{THE TECHNOLOGICAL SYSTEM PORTOMÍDIA}

Established in 2001, in its nineteen years of operations, the LPA Porto Digital has been consolidating itself as one of the main technology clusters in Brazil, with its investments focused on improving software development processes, which lead to the installation of hundreds of companies in the ICT sector in the State of Pernambuco (Porto Digital, 2020; 2010).

This LPA is a result of the articulation of an entrepreneurial nature that involves certain institutional actors, among them: the Government of Pernambuco, the Center for Advanced Studies and Systems of Recife (CESAR), the Information Center of the Federal University of Pernambuco (CIn / UFPE), as well as other agencies and private companies in the technology sector of the region, aiming at the economic and social development of the state of Pernambuco and having as a tool the ICT sector (Figure 1) (Silva, 2014; Corrêa, 2007).

Figure 1 - Governance Structure of the Porto Digital

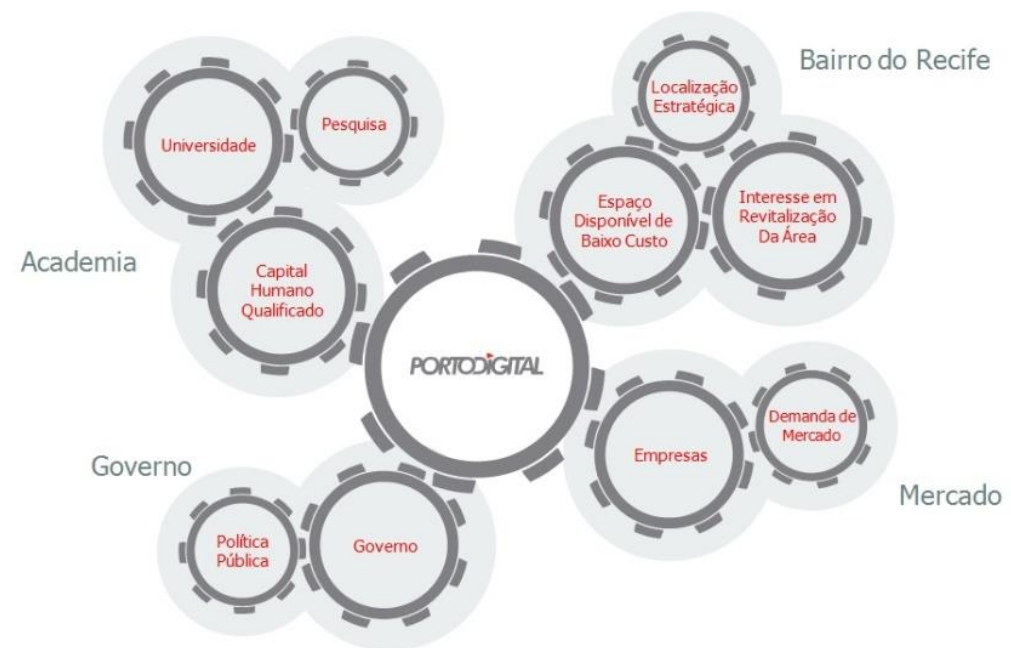

Source: Porto Digital, 2020.

In 2011, by means of the Municipal Law of Recife $n^{\circ} 17.762$, the Porto Digital announced its territorial expansion for a quadrilateral in the Santo Amaro neighborhood, as well as obtaining the concession of a program of fiscal benefits next to the establishments that settled in the Arrangement. This expanded its scope of action to incorporate the sectors of Creative Economy: multimedia, games, cinema, design, music and photography (Porto Digital, 2020, Cictec, 2013).

The expansion strategy of Porto Digital is added to a set of initiatives that have been taking shape in the city of Recife in the last decades, aiming at the development and dynamization of the city's economy. In addition to these initiatives, the "Selected Productive Chains in Recife" research, developed by the Center for Management and Strategic Studies (CGEE, 2011), was carried out. Its main objective was to contribute to the establishment of a new dynamic to operate in the economy in addition to developing technological innovation in the main productive chains of the City.

The development of strategies aimed at providing dynamism and competitiveness to the economy of the City of Recife relies on what authors like Mazzucato \& Penna (2016) and Lee et al. (2020) described as the articulation of key actors that mobilize the organizational structures and the broader institutional frameworks aimed at attracting fundamental resources in order to meet their visions with the future of the enterprises they lead. 


\section{RESULTS AND DISCUSSION}

The results and discussions of this topic are being made possible through the analysis of the LPA Porto Digital case under the conceptual reading based on the multidimensional-reflexive model of organization (OMR) conceived by Sérgio Alves. The purpose of such a framework lies in helping to understand the manifestation of the structure and agent in the process of converting the ICT LPA Porto Digital, in Portomídia, a pole of Creative Economy. We will observing dimensions associated with the institutional environment, structural characteristics and devices coordination, the characteristics of the main agent and the flow of activities, oriented from the OMR model.

\subsection{Institutional Environment of LPA Porto Digital}

The Porto Digital is a Social Organization (OS) that follows parameters established by State Law $\mathrm{n}^{\circ}$ 11.743/2000 and Decree $n^{\circ}$ 23.046/2001, which qualifies Social Organizations, in addition to the State Decrees $n^{\circ}$ $33.817 / 2009, n^{\circ} 36.744 / 2011$ and $n^{\circ} 40.568 / 2014$, which [re]qualify the Social Organization (NGPD), an entity responsible for governance of the territory where the Porto Digital cluster is located (Pernambuco, 2011, 2014).

The relationship between the Government of the State of Pernambuco and the NGPD Social Organization is mediated by state secretariats that can enter into commitments through management contracts supervised by the PEMEX and the General Comptroller's Office of the State of Pernambuco. State (CGE), as can be seen in the clipping of one of the interviews (E6) presented below:

The Porto Digital chose to be a Social Organization (O.S.). When it was said: - ah, let's create the Porto Digital, let's create a Local Innovation System, let's create a Technology Park, created already under a management model entitled "Social Organization". Social Organization, are civil society organizations, are private non-profit entities that implement public policies, not exclusive, by state delegation, whether at the federal, state or local level. This was part of the reform of the State of 1998, the Government was FHC, the Minister was Bresser, many called the Bresser law, which creates the O.S.'s and the OSCIP's. It is not a legal reason, O.S., and yes, a title you receive from the state in order to implement public policies. The instrument that ties the O.S.'s relationship to the State is the Management Contract. The Management Contract is a contract that closely resembles private contracts, where the O.S., which is a private entity, through a very detailed work program, undertakes to deliver goals to the Government and, on the other hand, the Government transfers resources to sustain these O.S.'s and feed their ability to deliver those goals. So, the basis of the management model of the Porto Digital is the basis of the management model of a generic O.S. (E6, 188-205).

We observed that the management model used by LPA Porto Digital approached the structural type of liberator-transformer (Costa, 2011), since it emphasized in its management model: innovation, creativity, initiative, flexibility. Therefore, it was verified that in the process of taking the objectives established and the routines built with the social actors involved, take place in the sense of building a territorial system of innovation balanced and managed as a Social Organization, materialized in the Nucleus of Management of the Porto Digital (NGPD). In the next subsection, we will emphasize how the structural characteristics and the management devices of LPA Porto Digital. According to Maillat (2016) the articulation of the actors in a given territory stimulates an innovative environment, generates endogenous development processes and adapts to global competitiveness.

\subsection{Structural Characteristics and Coordination Devices}

The management of the LPA Porto Digital follows the theoretical model of "Triple Helix" (Etzkowitz \& Leydsorff, 1997), according to which University, Government and Company interact in the production of concepts and knowledge related to the problems of the business sector. In this case, the interview clipping (E6) below illustrates neither that the demanding sectors of ICT and Creative Economy are linked to the structure of the LPA Porto Digital, as well as the commercialization of the unfolding of this production.

We take seriously what the theory of management of Local Systems Innovation, in the last 15 years, has been emphasizing a lot, which is the concept of the triple helix. In fact, a lot of people talk, and it is difficult 
to talk about because they are three different cultures, they are three different dynamics, three ways of seeing the different world, but we shared the reality diagnosis of Recife, shared the strategy and shared the management. So, the Board of Directors of O.S. - Porto Digital is made up of representatives of the Government, representatives of the University, representatives of the market, companies, and a group of representatives of society that are not necessarily institutional, but which are notable people from the field of culture, heritage, etc., given the characteristics of our neighborhood and, that we take this very seriously. We play things with a very interesting level of listening. We always try to get in touch with each other, companies with the University, companies with the Government, Government with the University, University with company, Government with company, in fact, we work all this in a very serious way (E6, 224-236).

The Social Regiment of LPA Porto Digital (2013, p. 4) establishes the creation of bodies that constitute the administration of Porto Digital, are: "Article 11 - The Management Boards of Porto Digital: a) the General Meeting; b) the Board of Directors; c) the Board". Specifically, the Board of Directors of Porto Digital is comprised of the performance of stakeholders related to ICT companies and their class representation, University representatives and government representatives. In the ambit of the Board of Directors, the procedures and initiatives that make it possible to make the Arrangement environment conducive to the development of the businesses of its specialty (ICT and Creative Economy) are deliberate. In the terms of Costa (2011) the regulations governing administrative and institutional activities deal with the rules and regulations that pave the functioning of the NGPD, which govern the entry and exit of companies, whose actions are provided for in Article 12 of the Bylaws (2013) and in the Internal Rules of the NGPD (NGPD, 2014, p. 3-4).

\subsection{Characteristics and performance of the Agent}

The dimension that values the characteristics and performance of the agent in LPA Porto Digital, even before the foundation of this Arrangement, involves the social actors who sought to make feasible in Recife City a set of initiatives to make the economy more competitive, according to Corrêa's study (2007) on "The new times and the discursive constitution of the collective subject". Therefore, there were already in Recife movements promoted by certain leaderships and aimed at creating projects that would develop the economy of the city of Recife, making it more dynamic, in addition to making feasible the economic-social development of the Pernambuco economy, in the face of the emerging paradigm of the economy of knowledge (Ouyang et al., 2017) supported by knowledge platforms, Local Innovation Systems, and the generation of high added value products and services.

The participation of the government is established at the state and municipal levels, through the activities of the State Secretariat for Science, Technology and Innovation (SECTI) (former SECTMA) and the City Hall of Recife (PCR), through the sectors related to development economic and social development, science, technology and innovation.

The activities of the agents linked to the University in the governance of the LPA Porto Digital takes place through the participation in projects and partnerships developed by the Information Center of the Federal University of Pernambuco (CIn/UFPE), since the 1990s when it was created. Among the main partnerships developed by CIn/UFPE, according to its Institutional Portal (2014), we highlight the close relationship with the Center for Studies and Advanced Systems of Recife (CESAR), where researchers and university students work professionally, the Center of Excellence in Software Technology of Recife (Softex) and Porto Digital itself. In addition, through IT Law No. 8.248/1991, the IT Center has collaborative relationships with companies such as Samsung, Itautec, Motorola, among others.

The activities of the agents linked to the private entities present in the governance of the Porto Digital are materialized through the representation of the private ICT entities, namely: The Center of Excellence in Software Technology of Recife (Softex); the Association of Brazilian Software Companies and Services and Computer Services (Assespro); the Center for Advanced Studies and Systems of Recife (Cesar).

There is a certain predominance of entities linked to the private initiative in the governance of the Porto Digital Arrangement, as one of the interviewees argues:

We have an intermediate instance called: tactical committee, which involves Porto Digital, ASSESPRO and SOFTEX, those more tactical components of the day-to-day in which the implementation of a certain strategic project for the sector has some difficulty. We meet and work together (E6: 422-425). 
The legislation of the City of Recife and the Bylaws of Porto Digital advocate its expansion into the scope of action - incorporating the creative sectors of cinema, audiovisual production, design, photography, games and multimedia - materialized in the creation of the Portomídia Arrangement. In practice, the structure of the Board of Directors of Porto Digital, as well as the other bodies related to LPA, remained intact, that is, without the presence of representations by creative economy companies, unlike ICT companies whose has a seat and is still represented by employers such as Assespro and Softex.

The Porto Digital has the advice that has some representation, but no one has a creative economy there, by the way, just have a guy there who is an artist. This is a very serious thing. The composition of the board of Porto Digital did not change with the expansion to the area of creative economy. So, institutional relations, I do not know to tell you. This is a complicated business! (E1: 304-308).

The Porto Digital will never turn its back on ICT. One clear clue is that the advice and composition of the council did not change. And it [the composition of the board of management of Porto Digital], has the ASSESPRO, has SOFTEX, companies, therefore, could have creative economy companies, but only have ICT companies. All the DNA of the Porto Digital is ICT (E1: 475-479).

In the excerpts from the interviews, we can note the construction of a beatified speech that is the protagonist of the individual action of social actors in the midst of the relations of strength in the scope of LPA Porto Digital, where the interest games, which permeate human and institutional, are materialized in the model of governance adopted and that allows the adhesion of other actors.

One of the interview leaders identified the need to expand the scope of LPA Porto Digital's operations, facing a complex scenario filled with political positions in dispute. This is evidenced by the pressure exerted by certain key actors in the Arrangement, such as the representation associations of software companies. They are protagonists of institutional initiatives aimed at creating a hub in the city of Recife that brings together projects linked to strategic sectors of Information and Communication Technology (ICT) and creative economy.

\subsection{Activity Flow}

The aspects related to the dimension that deals with the flow of activities illustrate the conception that the LPA Porto Digital has made efforts to consolidate its decision to expand to the field of the creative economy, through the creation of the Portomídia Arrangement. In this environment, entrepreneurs and artists with their respective peculiarities of cultural production dialogue among themselves and seek convergences that lead to the generation of products and services full of creative insights, amidst the fostering of regulatory frameworks for territories where the syncretism between technology, cultural practices flourish and business (Cictec, 2013).

The Portomídia is located in a total space of $500 \mathrm{~m}^{2}$ and has two training rooms equipped with state-of-theart computers and infrastructure for up to twenty students per room. It also has two hatcheries for ten companies, five laboratories for image, sound, design, animation and interactivity, and the most modern screen-test room for mixing and finishing sound and image of the country. This room will be equipped with state-of-the-art appliances, such as Light Base, which will allow 4K color and image processing in real time, scanner and 3D printer (prototyping). In addition, the Portomídia space has a $100 \mathrm{~m}^{2}$ exhibition room, equipped with interactive panels and displays (Porto Digital, 2020, p. 1).

If you go there in Portomídia, you get the hell out of it, 9 high tech labs, a training space, a digital arts gallery, a business incubator, that's a ghastly business (E6: 409-411).

According to information from the interviewees and secondary data obtained at the institutional portal of LPA Porto Digital, with the expansion of the territory and scope of action for creative economy, an infrastructure materialized in the acquisition of several technological equipment, physical spaces to provide the actors' meeting social activities involved in the new cultural equipment [Portomídia], diverse activities, such as the realization of specific courses for individuals that integrate the new enterprises of the creative economy incorporated into LPA Porto Digital, creation of incubators and accelerators of creative economy businesses (Porto Digital, 2020, Cictec, 2013).

In our findings, especially in the perspective of the agency's manifestation in the conversion of LPA Porto Digital to encompass Portomídia, we observe the discursive alignment between the main leaderships linked to the government (state and municipal departments), companies (mainly IT) and university (especially, from 
researchers linked to the UFPE Informatics Center), around the thesis to expand the scope and territory of LPA Porto Digital - which culminated in the creation of Portomídia and, later, the Armazém da Criatividade Technological Complex (characterizing the interiorization of the Porto Digital management expertise for cities in the interior of Pernambuco). The actions of these leaders, within the scope of LPA Porto Digital, seek synergy and complementarities.

Regarding the manifestation of the structure in the conversion of LPA Porto Digital to encompass Portomídia, as we have analyzed, state and municipal legislation has been adapted in order to guarantee the insertion of several creative sectors within the scope of Porto Digital's scope, the arrangement itself promoted changes in its statute and internal documents, which materialized in the creation of the Portomídia Technological System. However, an important observation that we realized in our analyzes is that, in order to give sustainability to the structure of Portomídia, Porto Digital needs to expand the dialogue with social actors linked to the creative economy businesses, as well as reflect on the reformulation of the Center of Porto Digital Management, ensuring seat and voice for these representations.

\section{FINAL CONSIDERATIONS}

This study had the objective of understanding how the structure and agent manifestation occurs in the process of converting LPA Porto Digital from the Portomídia, a pole of Creative Economy located in the neighborhood of old Recife (PE), oriented from the model OMR. Therefore, we elaborated the following research question: how does the process of conversion of the Porto Digital in the Portomídia in it is organizational-administrative format occur? Initially, we tried to understand from the analytic categories 'manifestation of structure' and 'agency' we sought answers to the dimensions associated with the institutional environment, structural characteristics and coordination devices, characteristics of the main agent and the flow of activities.

The Companies of creative economy domiciled at Porto Digital and Portomídia fit the type of liberativetransformer structural organization. Therefore, they are structured based on an incipient bureaucracy with a kind of reformist patriarchal management and business leadership records with charismatic traits that enables the development of innovative approaches and the generation of changes.

The adoption of the reformist patriarchal model is paramount for the preservation of the dynamism of both the Porto Digital and the Portomídia, especially with respect to the organizational profile of these LPAs that produce technological artifacts geared to the generation of knowledge, potentialized by creative processes inherent in the individuals who are permeated by transformations that are gradually absorbed by means of a continuous and systematic process of adjustments. Therefore, it is not possible to have such linear changes in the midst of the business dynamics in these productive arrangements, but to develop a process of cyclical transformations that contemplate the demarcation of structural changes.

In this way, the agents that enable the governance of these LPAs must guarantee the maintenance of an environment appropriate to the innovative context and try to avoid contradictions and setbacks that represent obstacles to the increase of their competitive performance.

Finally, future studies can be deepened in the understanding of aspects of the dynamic reality of institutional Arrangements, specifically, with respect to the relation of the organizational structure established in certain technological systems, in order to make possible to identify possible changes or migrations of configurations of undertakings that advocate collective efficiency for other structural types that can be understood through models such as the OMR format. 
CONVERSION OF AN INFORMATION AND COMMUNICATION TECHNOLOGY CLUSTER TO A POLE OF CREATIVE ECONOMY: AN ANALYSIS FROM THE PERSPECTIVE OF SÉRGIO ALVES' MULTIDIMENSIONAL-REFLEXIVE MODEL OF ORGANIZATION ANDERSON DIEGO FARIAS DA SILVA, OSÍRIS LUÍS DA CUNHA FERNANDES, FERNANDO GOMES DE PAIVA JÚNIOR, JANANN JOSLIN MEDEIROS, NELSON DA CRUZ MONTEIRO FERNANDES

\section{REFERENCES}

AGUIAR, N. Patriarcado, sociedade e patrimonialismo. Sociedade e Estado, v. 15, n. 2, p. 303-330, 2000.

ALMEIDA, B. C.; PAULA, S. L. Aplicação do modelo multidimensional-reflexivo para análise de uma entidade pública municipal: Autarquia de Esporte e Lazer do Recife (PE). Revista Gestão \& Políticas Públicas, v. 2, n. 1, 2013.

ALVES, S. A multidimensionalidade nas organizações empresariais: proposta de um modelo analítico. Revista de Administração Contemporânea, v. 8, n. 2, p. 71-93, 2004.

Edufpe, 2003.

Racionalidade, Carisma e Tradição nas organizações empresariais contemporâneas. Recife:

BACH, M. Carisma e racionalismo na sociologia de Max Weber. Sociologia \& antropologia, v. 1, n. 1, p. 5170, 2011.

BERTERO, C. O. Tipologias e teoria organizacional. Revista de Administração de Empresas, v. 21, n. 1, p. 338, 1981.

CASSIOLATO, J. E.; Lastres, H. Sistemas de Inovação e Desenvolvimento: as implicações de política. Scielo. São Paulo: EM PERSPECTIVA, v. 19, n. 1, p. 34-45, jan./mar. 2005.

CASTELLS, M. A sociedade em rede. 17 ed. São Paulo: Paz e Terra, 2016.

CGEE. Inovações Tecnológicas e Cadeias Produtivas selecionadas: Oportunidades de negócios para o município de Recife (PE). Brasília: Centro de Gestão e Estudos Estratégicos, 2011.

CICTEC. $3^{o}$ Seminário CICTEC: Inovação e Competitividade na Economia Criativa. Recife: Centro de Inteligência Competitiva para Parques Tecnológicos, 2013.

CORRÊA, M. I. S., Os novos tempos e a constituição discursiva do sujeito coletivo: um estudo no campo de empreendedorismo no setor de tecnologia da informação e comunicação. Dissertação de Mestrado. Recife: Programa de Pós-Graduação em Administração da Universidade Federal de Pernambuco (PROPAD/UFPE), 2007.

COSTA, M. G. S. A configuração organizacional-administrativa de Instituições de Ensino Superior Confessionais no Estado de Pernambuco, à luz do Modelo Multidimensional-Reflexivo. Dissertação (Curso de Mestrado). Recife: UFPE, 2011.

CRESWELL, J. W. Projeto de Pesquisa: métodos qualitativo, quantitativo e misto. 3.ed. Porto Alegre: Artmed/Bookman, 2010.

DATTAGUPTA, O. Global Integration and Developing Indian "SmartCities": New Hopes and Challenges: International Journal of Innovative Social Science \& Humanities Research. Vol (1), Issue-2, December-2014.

DENZIN, N. K.; LINCOLN, Y. S. O planejamento da pesquisa qualitativa: teorias e abordagens. 2. ed. Porto Alegre: Bookman, 2006. 432 p. 
CONVERSION OF AN INFORMATION AND COMMUNICATION TECHNOLOGY CLUSTER TO A POLE OF CREATIVE ECONOMY: AN ANALYSIS FROM THE PERSPECTIVE OF SÉRGIO ALVES' MULTIDIMENSIONAL-REFLEXIVE MODEL OF ORGANIZATION ANDERSON DIEGO FARIAS DA SILVA, OSÍRIS LUÍS DA CUNHA FERNANDES, FERNANDO GOMES DE PAIVA JÚNIOR, JANANN JOSLIN MEDEIROS, NELSON DA CRUZ MONTEIRO FERNANDES

DIÁRIO OFICIAL DO ESTADO DE PERNAMBUCO. Decreto $n^{\circ} 36.744$, de 07 de julho de 2011. Companhia Editora de Pernambuco - CEPE: Recife, 2014, p. 9, nº 129.

DIÁRIO OFICIAL DO ESTADO DE PERNAMBUCO. Decreto $n^{\circ} 40.568$, de 01 de abril de 2014. Companhia Editora de Pernambuco - CEPE: Recife, 2014, p. 7, nº 61.

ESTATUTO SOCIAL DO PORTO DIGITAL. Recife: Portal Institucional do Porto Digital, 2013.

ETZKOWITZ, H.; LEYDSDORFF, L. Universities in the global knowledge economy: a triple helix of academic-industry-government relations. London: Cassel, 1997.

GASKELL, G.; BAUER, M. W. Para uma prestação de contas pública: além da amostra, da fidedignidade e da validade. In: Bauer, M. W.; Gaskell, G. Pesquisa qualitativa com texto, imagem e som: um manual prático. Petrópolis: Vozes, 2002.

HOWELLS, J. Global innovation: innovation systems in open and distributed networks. In: The Handbook of Globalisation, Third Edition. Cheltenham, UK: Edward Elgar Publishing, 2019.

JULIEN, P-A. Empreendedorismo regional e economia do conhecimento. São Paulo: Saraiva, 2010.

KIRSCHBAUM, C. Indústrias Criativas no Brasil / coordenadores Charles Kirschbaum... [et al.] - São Paulo: Atlas, 2009.

KNORRINGA, P.; NADVI, K. RISING power clusters and the challenges of local and global standards. Journal of Business Ethics, v. 133, n. 1, p. 55-72, 2016.

LASTRES, H. M. M.; CASSIOLATO, J. E. Novas políticas na era do conhecimento: o foco em arranjos produtivos e inovativos locais. Parcerias estratégicas, v. 8, n. 17, p. 05-30, 2010.

LEE, Sungjoo; LEE, Hakyeon; LEE, Changyong. Open innovation at the national level: Towards a global innovation system. Technological Forecasting and Social Change, v. 151, p. 119842, 2020.

LINCOLN, Y. S.; GUBA, E. G. Naturalistic inquiry. London: Sage Publications, 1985.

LINS, DANIEL; CORREIA, Milka Alves. O Caso Nissan: superação da antinomia liderança versus burocracia? Review of International Business, v. 3, n. 1, p. 72-91, 2008.

MAILLAT, D. Globalização, meio inovador e sistemas territoriais de produção. Interações (Campo Grande), v. 3, n. 4, 2016.

MAZZUCATO, Mariana; PENNA, Caetano. The Brazilian innovation system: a mission-oriented policy proposal. Avaliação de Programas em CT\&I. Apoio ao Programa Nacional de Ciência (Plataformas de conhecimento). Brasília, DF: Centro de Gestão e Estudos Estratégicos, 2016.

MINGUILLO, D., TIJSSEN, R., \& THELWALL, M. Do science parks promote research and technology? A scientometric analysis of the UK. Scientometrics, 102 (1), 701-725. (2015).

MORAES, L. F. R.; MAESTRO FILHO, A. D.; Dias, D. V. O paradigma weberiano da ação social: um ensaio sobre a compreensão do sentido, a criação de tipos ideais e suas aplicações na teoria organizacional. $R A C$, v. 7 , 
CONVERSION OF AN INFORMATION AND COMMUNICATION TECHNOLOGY CLUSTER TO A POLE OF CREATIVE ECONOMY: AN ANALYSIS FROM THE PERSPECTIVE OF SÉRGIO ALVES' MULTIDIMENSIONAL-REFLEXIVE MODEL OF ORGANIZATION ANDERSON DIEGO FARIAS DA SILVA, OSÍRIS LUÍS DA CUNHA FERNANDES, FERNANDO GOMES DE PAIVA JÚNIOR, JANANN JOSLIN MEDEIROS, NELSON DA CRUZ MONTEIRO FERNANDES

n. 2, p. 57-71, 2003.

OUYANG, Qiqing Christine et al. Collaborative Innovation Centers (CICs): Toward Smart Service System Design. In: Serviceology for Smart Service System. Springer Japan, 2017. p. 385-391.

PORTO DIGITAL. Institucional: APL. Recife: Porto Digital, 2020. Disponível em: <http://www.portodigital.org.br/>. Acesso em: 03 de jan. 2020.

Perfil Geral do Porto Digital. Recife: Porto Digital, 2010.

RAMOS, Guerreiro. A sociologia de Max Weber: sua importância para a teoria e a prática da administração. Revista do Serviço Público Brasília, 57 (2): 267-282 Abr/Jun, 2006.

RECIFE. Decreto Municipal no 20.508/2004. Diário Oficial da Prefeitura do Recife, Poder Executivo.

Lei Municipal no 16.731/2001. Diário Oficial da Prefeitura do Recife, Poder Executivo. Disponível em: 〈http://www.legiscidade.recife.pe.gov.br/lei/16731/>. Acesso em 25 jun. 2014.

. Lei Municipal no 17.244/2006. Diário Oficial da Prefeitura do Recife, Poder Executivo. Disponível em: <http://www.recife.pe.gov.br/sefin/legislacao/lei17244.php>. Acesso em: 10 ago. 2013.

. Lei Municipal $n^{\circ} 17.762 / 2011$. Introduz alterações nas Leis Municipais $n^{\circ} 17.244 / 2006$ e $n^{\circ}$ 17.237/2006. Diário Oficial da Prefeitura do Recife, Poder Executivo. Recife, PE, 29 dez. 2011. Edição 151.

REGIMENTO INTERNO DO NGPD. Recife: Porto Digital, 2014. Disponível em: < http://www2.portodigital.org/portodigital/ARQUIVOS_ANEXO/regimento\%20interno;;20061006.pdf>. Acesso em: 28 jun. 2014.

SILVA, A. S.; Neto, A. C. Uma contribuição ao estudo da liderança sob a ótica weberiana de dominação carismática. RAM - Rev. Adm. Mackenzie, v. 13, n. 6, Ed. Especial, São Paulo, nov./dez, 2012.

STAKE. The art of case study research. 2 ed. London: Sage Publications, 1999.

Qualitative Case studies. In: Denzin, N. K.; Lincoln, Y. S. (Eds.) The Sage handbook of qualitative research. London: Sage Publications, 2005.

TEIRLINCK, Peter. Is there an industry-science mismatch in the Brussels agglomeration? Evidence from knowledge spillovers in innovation active SMEs in knowledge intensive business services (KIBS). Brussels

Studies. Collection générale, $\mathrm{n}^{\circ}$ 108, 2017. Disponível em: <http://brussels.revues.org/1467; DOI: 10.4000/brussels.1467>. Acesso em 15 de mar. 2017.

XAVIER FILHO, J. L. J.; PAIVA JÚNIOR, F. G.; XAVIER, M. L. Desistência da Cooperação em Redes Inter organizacionais Horizontais: Reflexões a partir da Tipologia da Ação Social Weberiana. XVI Seminários em Administração (SEMEAD), XVI. In: Anais do XVI Seminários em Administração (SEMEAD). São Paulo: FEA/USP, 2013.

WEBER, M. A ética protestante e o espírito do capitalismo, São Paulo: Pioneira, 1985. Economia e Sociedade. v. 2. Revisão - Gabriel Cohn. Brasília: UnB, 1999. 
CONVERSION OF AN INFORMATION AND COMMUNICATION TECHNOLOGY CLUSTER TO A POLE OF CREATIVE ECONOMY: AN ANALYSIS FROM THE PERSPECTIVE OF SÉRGIO ALVES' MULTIDIMENSIONAL-REFLEXIVE MODEL OF ORGANIZATION ANDERSON DIEGO FARIAS DA SILVA, OSÍRIS LUÍS DA CUNHA FERNANDES, FERNANDO GOMES DE PAIVA JÚNIOR, JANANN JOSLIN MEDEIROS, NELSON DA CRUZ MONTEIRO FERNANDES

. Ensaios de sociologia. Organização e introdução de H. H. Gerth e C. W. Mills. 3. ed. Rio de

Janeiro: Zahar Editores, 1974.

YIN, R. K. Estudo de Caso: planejamento e métodos. $3^{\text {a }}$ ed. Porto Alegre: Bookman, 2005. 